\title{
Application Of Trial Finalization System As Determinants Of Final Thesis Session Results
}

\author{
Untung Rahardja ${ }^{1}$, Dwi Andayani ${ }^{2}$, Nabila Cynthia Aristo ${ }^{3}$, Zainal Arifin Hasibuan ${ }^{4}$ \\ University of Raharja ${ }^{1,2,3}$, Indonesia University ${ }^{4}$ \\ Jl. Jenderal Sudirman No.40, Cikokol, Kec. Tangerang, Kota Tangerang, Banten 15117 \\ e-mail: untung@raharja.infol ${ }^{1}$,dwi.andayani@raharja.info ${ }^{2}$, zhasibua@cs.ui.ac.id ${ }^{3}$, \\ nabila.cynthia@raharja.info ${ }^{4}$
}

To cite this document:

Rahardja, U., Andayani, D., Aristo, N., \& Hasibuan, Z. (2019). Application of Trial

Finalization System As Determinants of Final Thesis Session Results. IAIC Transactions on Sustainable Digital Innovation, 1(1), 1-7. Retrieved from https://aptikom-

journal.id/index.php/itsdi/article/view/4

\begin{abstract}
The objective assessment system and guiding assessment can be accessed online, but the examiner's assessment system in which there is a system of finalizing the trial still using the local network and not connected with the others. The trial appraisal system that was not mutually integrated made the examiner a little difficult. This is because as technology advances are utilized as well as possible by educational institutions in this case namely universities to be used in a comprehensive session of thesis students or final assignments. Then it is necessary to develop the examiner's assessment system in which there is a system of finalizing the trial. The research was conducted using the method of observation, interviews and literature studies to maximize this research. The researcher directly examines the congregation assessment system which still uses the local network to analyze how the system works so that when carried out development does not change the existing system flow. Interviews were also conducted by researchers to collect data from existing speakers, namely the board of examiners. Then the author searched the list of previous studies that are appropriate so that repetition does not occur. After the development of the examiner's assessment system along with the finalization of the session and making the system integrated with each other so as to facilitate the examiner chairman to use it in determining whether or not students are declared eligible to pass a comprehensive trial or not. This proved that the system that had been developed greatly helped the process of the trial.
\end{abstract}

Keywords: Finalization, Assessment, Comprehensive Session

\section{Introduction}

Thesis Session is a process of presenting students about final research that has been considered completed by being recorded in a writing report form. Students present the results of their scientific work when the trial takes place before the board of examiners. When the trial took place the board of examiners assessed the results of the scientific work that had been done by the students whether it was feasible to graduate or not. Assessment can be

interpreted as a process of collecting and processing information that aims to be used in making decisions to determine the quality of students. Assessment can also be used as a reference to obtain information about students how well the learning outcomes have been achieved by students. The results of the assessment can be quantitative values (numbers) and 


\section{IAIC Transactions on Sustainable Digital Innovation (ITSDI) Vol. 1 No. 1 October 2019}

qualitative values (narrative statements in words). Assessment is positive attitudes and perceptions of knowledge, acquisition and integration of knowledge, expansion and deepening of knowledge, meaningful use of knowledge, and habits of productive thinking (I Wayan Suastra 305-2016).

In the world of education today it is certainly not separated from the use of computer technology as one of the many media that provide benefits. Technology is now not only reaching offices but also other agencies such as universities. However, the fulfillment of the need for information at this time cannot be separated from the use and utilization of computers to the maximum extent possible. Compared to the absence of technology, the lack of understanding of computer technology inhibits access or the running of an academic institution to the outside world. The use of technology in the field of education is indeed very rapid, so many universities have used technology in every activity.

In a thesis session or final assignment, determining the final outcome of the trial is very necessary to see whether students are eligible or not based on their scientific work. After students make presentations of their scientific work, then the board of examiners conducts a question and answer session to give a test of what was said by the student. Value input is done after it is considered sufficient in the question and answer session and the session is closed. After inputting the value, it is then finalized by the chairman of the meeting whether the students who present at the session are eligible to be declared pass or not.

The objective assessment system and guiding assessment can be accessed online, but the examiner's assessment system in which there is a system of finalizing the trial still using the local network and not connected with the others. The trial appraisal system that was not mutually integrated made the examiner a little difficult. As long as the trial process takes place from the start of the trial until it closes, all are facilitated by a trial assessment system that is already online, of course. This makes an educational institution or university make good use of current technological developments by implementing a trial assessment system which includes inputting the value and finalizing the session. The trial appraisal system that is used such as objective assessment and guiding assessment can be accessed online, but the examiner's assessment system in which there is a system of finalizing the trial still using the local network and not connected with the others. The trial appraisal system that was not mutually integrated made the examiner a little difficult. This of course requires action to be developed so that it can be integrated with each other.

\section{Research Method}

This study uses several research methods to support this research to the maximum extent possible. The researcher observes a university to see the system used to finalize the session. Then the researcher conducted an interview to the board of examiners how the experience of using the trial assessment system. The entire board of examiners said that they were greatly helped by the hearing assessment system because it was user friendly so the trial process proceeded smoothly. The finalization process was also done well because the system was very informative. Then the researcher also conducted a literature study to look for references to similar research in the form of a literature review.

\section{Literature Review}

Efforts to improve the system of finalizing the hearing, there are several literature reviews that have been prepared to avoid repetition, and continue the research that has previously been done. Some literature reviews include the following:

1. The research was conducted by Erick in 2019 with the title "Test Appraisal System Application Based on YII Framework As a Media Input of Student Values for Final Project Session and Thesis at Higher Education". The study explained that the Testing 
Assessment System is very important in the process of running a thesis trial or final assignment, because it makes it easier for lecturers to provide an assessment of the results of student thesis research. However, in the current assessment system, testers have problems, namely still using local networks, which of course are still using UTP cables as their connectors. From these problems, it is necessary to develop examiners' assessments so that they can be accessed more systematically, organized, can be accessed online.

2. The research entitled "Test Assessment System in Pessta + S2 Based on Yii Framework as a Media for Inputting the Value of Thesis Sessions in Higher Education" conducted by Yulianto in 2018, discussing the assessment system of examiners currently has a problem that is still conventional in which the examiners fill in a written assessment not yet applied online. From these problems, it is necessary to develop the assessment of examiners so that they can be accessed online so that they become more systematic, organized, effective and efficient and can be accessed online.

3. This research was conducted by Mohamad Farozi, M. Suyanto, Emha Taufiq Lutfi in (2015), entitled "DESIGNING INFORMATION SYSTEMS FOR ASSESSMENT OF HUMAN RESOURCES PERFORMANCE USING THE GAMIFICATION METHOD". The design of the HR performance assessment information system with the gamification method is displayed through the website and allows the challenges (tasks and responsibilities) of employees to be more fun to work on, users (employees) will be given points and badges (reward) when successfully completing challenges and other users (employees) can see the performance of each user (employee) through the leaderboard.

4. The research conducted by Sudaryono in 2018 with the title "Assessment of Guidance as a Media Inputting Student Values at PESSTA + in Higher Education" discussing Advisory Assessment is very important to facilitate lecturers in providing assessment of counselors directed to students. However, in the scoring system the supervisor currently has a problem that is still using a local network that can only be accessed while on campus.

5. The research entitled "Overview of Budgeting and Its Realization As a Tool for Corporate Performance Evaluation at PT Taspen (Persero) KCU Bandung" was conducted by Nurhafid in 2017. This research was conducted to find out how the budget preparation and realization at PT TASPEN (Persero) Main Branch Office Bandung which will be used as a company performance assessment tool In this final assignment descriptive method is used, namely a research method whose purpose is to solve, analyze, and classify the data that has been obtained and then draw conclusions so that it can provide a clear picture of the object which will be examined with the problems that will be discussed in this final report.

6. This research was conducted by Muhammad Kadafi in 2017 with the title "Preparation of Standard Operating Procedures (Sop) Study Programs at Samarinda State Polytechnic Which Refer to the Assessment of Accreditation Standards of the National Accreditation Board for Higher Education (Ban-pt) Using the Mind Manager Program and Microsoft Visio". This study aims to compile (design) Standard Operating Procedures (SOPs) of study programs that evaluate the BAN-PT accreditation standards. Researchers use the Miles and Huberman model, namely data collection, reduction, presentation, and conclusion. The results of the conclusions are contained in the document flow chart.

\section{Findings}

The trial assessment system has been carried out online now, making it easier for the board of examiners to input values because they are mutually integrated. But before this 
IAIC Transactions on Sustainable Digital Innovation (ITSDI)

Vol. 1 No. 1 October 2019

research was carried out everything was still separate because of the different process of developing the system.

\subsection{Problem}

The finalization system of the previous trial had indeed already existed and was used at the final session of the students, but still using the local network. In the trial scoring system there are 3 components of assessment, namely objective assessment, guidance and examiners. On the objective assessment students can be accessed online and independently by students, as well as the assessment of the counselor has also been incorporated into one system with objective assessments so that the assessment of the session becomes separate. The finalization system is in the assessment of the examiner so that it is separate from other assessments.

With the existence of these problems, the examiner's assessment system was also further developed with a finalization system. After the development of a testing appraisal system, the trial assessment system has been integrated with each other and made it easier for the board of examiners to finalize the trial.

\subsection{Research Implementation}

The finalization of the trial system that has been integrated with each other has been implemented or applied at the end of odd semester and even semester sessions by an educational institution, namely Higher Education. This makes the board of examiners easier to use, not only systems that are mutually integrated and also display that is user friendly.

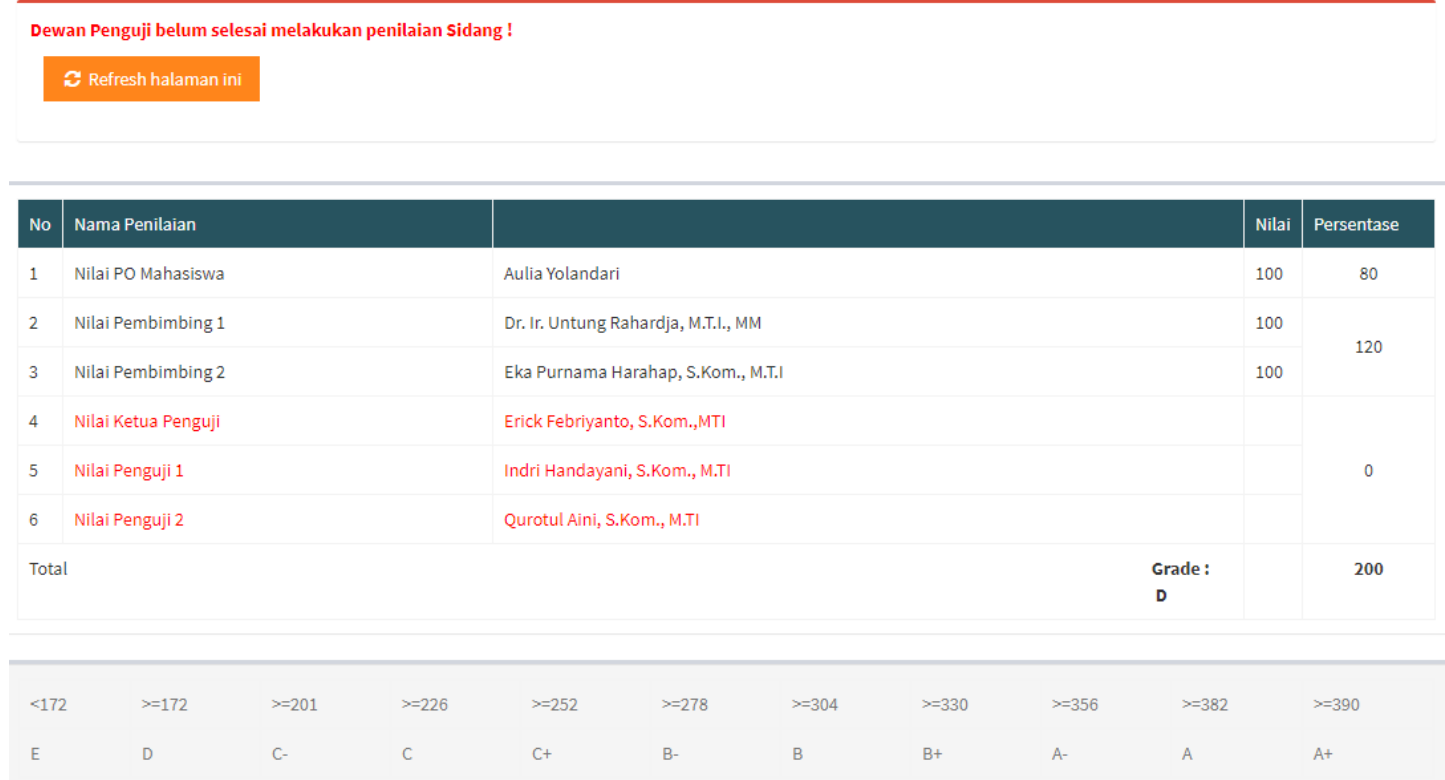

Figure 1. Display before the entire board of examiners input values

Figure 1. is a display picture of the finalization of the trial before the board of examiners has not made inputting values. Because the congregation's integrated assessment system makes it easy for the board of examiners to look at other trial assessment component

information. Can be seen as to what objective assessment students have collected, then what value is given by the supervisor to students. So that the board of examiners can determine what value he will give to students. Not only that, the board of examiners can also see what 
IAIC Transactions on Sustainable Digital Innovation (ITSDI)

Vol. 1 No. 1 October 2019

grade the student will get after finalization by the chief examiner so that the board of examiners can also arrange it.

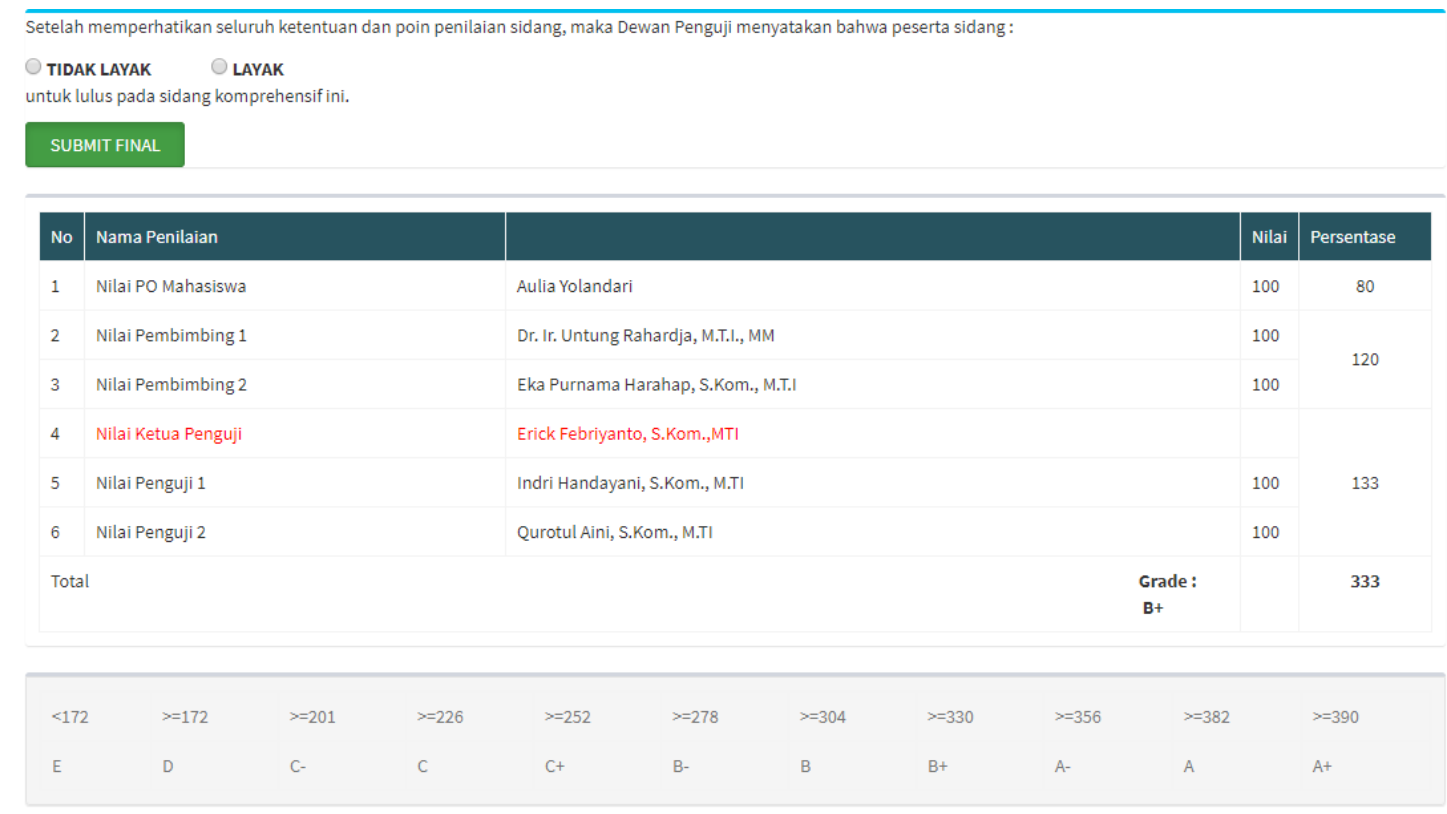

Figure 2. Display after the board of examiners input values

Figure 2. is a display of the finalization of the session when the two board of examiners have inputted the value. Furthermore, the task of the examiner chairman to provide value before determining which student is eligible for graduation or even to repeat his research again because it is proven to violate the provisions given.

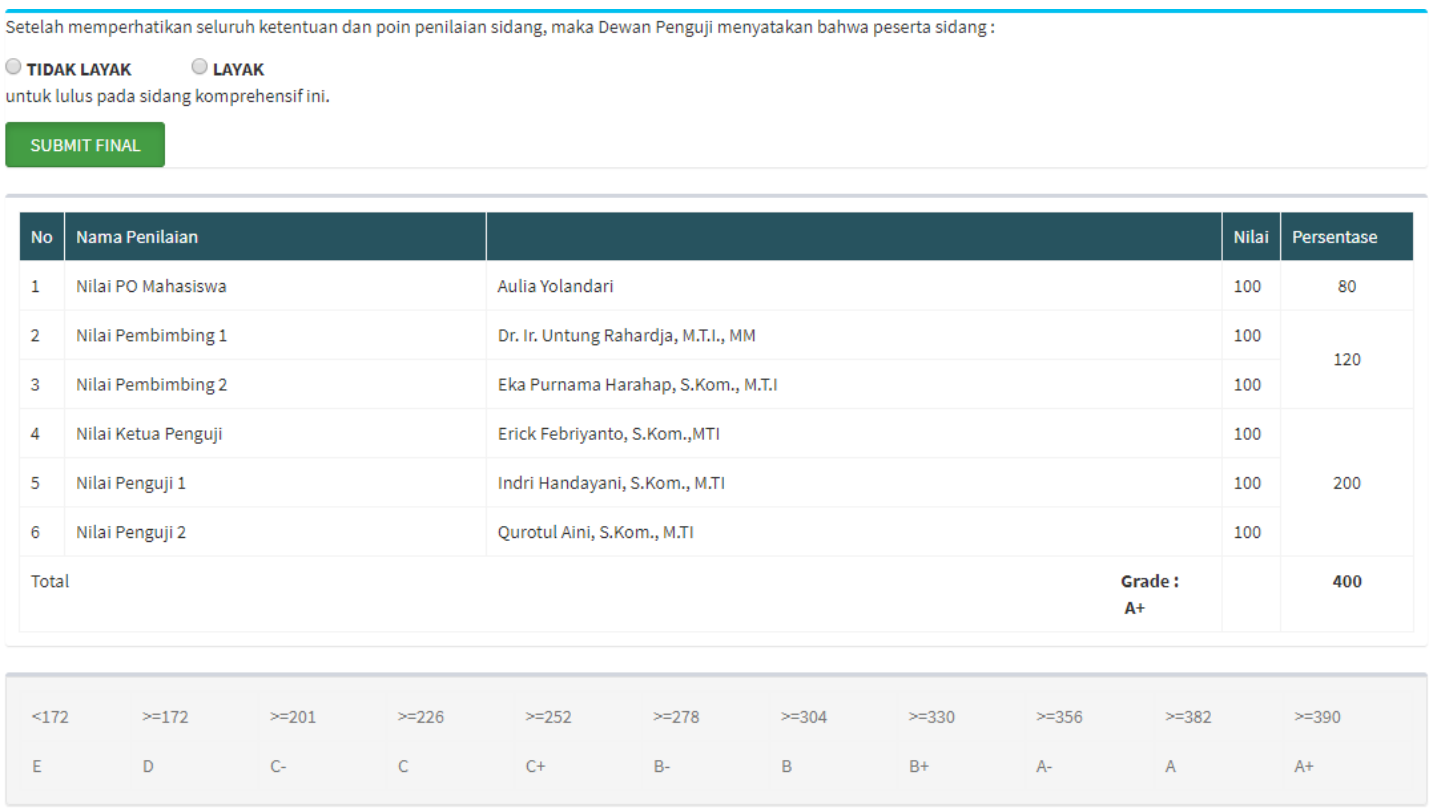

Figure 3. Display of Chair Examiners finalizing

Figure 3. is a display of the examiner chairman after inputting the value and carrying out the 
IAIC Transactions on Sustainable Digital Innovation (ITSDI)

Vol. 1 No. 1 October 2019

next assignment for the chairman of the examiner to finalize the final session. The task of the chairman of the examiner is only to determine whether a proper or inappropriate student is graduated at a comprehensive session after discussion with the other two board of examiners.

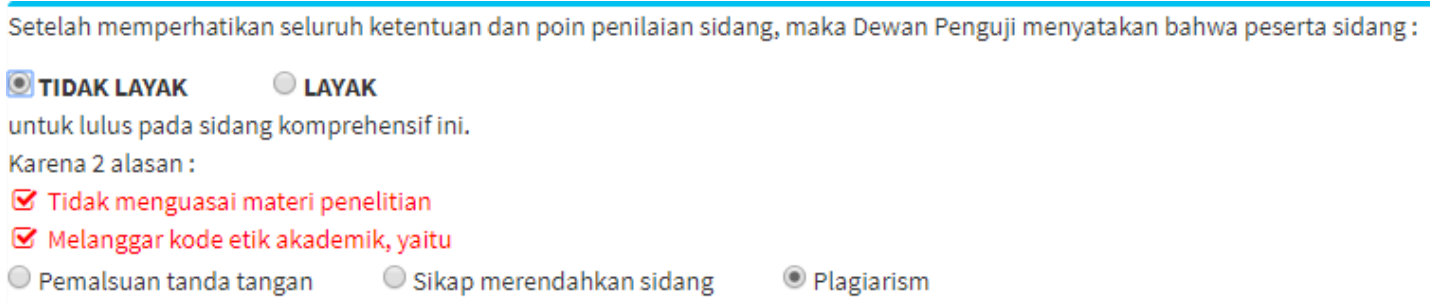

\section{SUBMIT FINAL}

Figure 4. Criteria for students not eligible to graduate

Figure 4. above is a display if the chairman of the examiner chooses that the student is not eligible for the trial to be passed because it violates established rules such as:

1. Not mastering research material

2. Violates the academic code of ethics such as:
a. Signature forgery
b. Condescending attitude of the congregation
c. Plagiarism

If students violate among the list of violations, students are declared unfit to graduate in a comprehensive hearing.

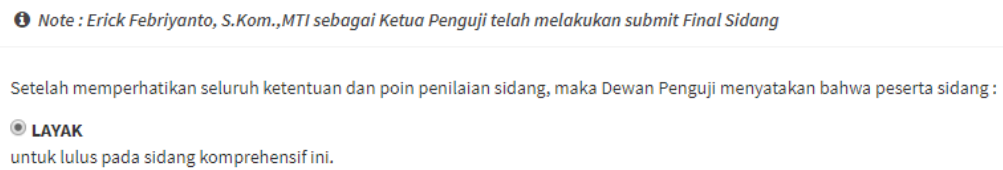

\begin{tabular}{|c|c|c|c|c|c|c|c|c|c|c|c|}
\hline No & \multicolumn{3}{|l|}{ Nama Penilaian } & & & & & & & Nilai & Persentase \\
\hline 1 & \multicolumn{3}{|l|}{ Nilai PO Mahasiswa } & \multicolumn{6}{|c|}{ Aulia Yolandari } & 100 & 80 \\
\hline 2 & \multicolumn{3}{|l|}{ Nilai Pembimbing 1} & \multicolumn{6}{|c|}{ Dr. Ir. Untung Rahardja, M.T.I., MM } & 100 & \multirow{2}{*}{120} \\
\hline 3 & \multicolumn{3}{|l|}{ Nilai Pembimbing 2} & \multicolumn{6}{|c|}{ Eka Purnama Harahap, S.Kom., M.T.I } & 100 & \\
\hline 4 & \multicolumn{3}{|l|}{ Nilai Ketua Penguji } & \multicolumn{6}{|c|}{ Erick Febriyanto, S.Kom.,MTI } & 100 & \\
\hline 5 & \multicolumn{3}{|l|}{ Nilai Penguji 1} & \multicolumn{6}{|c|}{ Indri Handayani, S.Kom., M.TI } & 100 & 200 \\
\hline 6 & \multicolumn{3}{|l|}{ Nilai Penguji 2} & \multicolumn{6}{|c|}{ Qurotul Aini, S.Kom., M.TI } & 100 & \\
\hline \multicolumn{7}{|c|}{ Total } & & \multicolumn{3}{|c|}{ Grade: A+ (Lulus) } & 400 \\
\hline$<17$ & $>=172$ & $x=201$ & $>=226$ & $>=252$ & $x=278$ & $x=304$ & $>=330$ & $x=356$ & $x=382$ & & $>=390$ \\
\hline E & D & c- & c & $\mathrm{c}+$ & B- & B & B+ & A- & A & & At \\
\hline
\end{tabular}

Figure 5. Display after finalizing the session

Figure 5. above is a display after the chairman of the examiner has inputted the value and finalization of the session can be seen that students have been declared eligible by the board 
of examiners with the value of the details of grades and final grade obtained by students. After the chief examiner finalizes the board of examiners can no longer carry out activities such as replacing the inputted value. Change of value can be done before the examiner chairman finalizes the session.

\section{Conclusion}

With a trial assessment system that has been fully developed, it includes objective assessment, guidance assessment, until the assessment of the examiner and finalization of the session makes the process of the proceedings run smoothly, of course, because the system is integrated with each other. This also makes it easy for the board of examiners to input values. Not only that, the chairman of the examiner also felt helped by the finalization system that was connected with the assessment of other congregations. This is because the display is user friendly so that it makes it easier for the chief examiner to make decisions easily to determine a student to be declared passed or not at a comprehensive hearing. This proved that the system that had been developed greatly helped the process of the trial.

\section{References}

[1] Suastra, I. W., \& Ristiati, N. P. (2016). PERMASALAHAN GURU DALAM MERANCANG DAN MENGIMPLEMENTASIKAN PENILAIAN OTENTIK DALAM PEMBELAJARAN SAINS DI SMP DAN SMA. In Seminar Nasional Riset Inovatif (Vol. 4).

[2] Febriyanto, E., Handayani, I., \& Suprayogi, D. (2019). Aplikasi Sistem Penilaian Penguji Berbasis YII Framework Sebagai Media Input Nilai Mahasiswa Sidang Tugas Akhir Dan Skripsi Pada Perguruan Tinggi. CSRID (Computer Science Research and Its Development Journal), 10(2), 113-125.

[3] Handayani, I., Yulianto, Y., \& Khumaida, F. A. (2019). SISTEM PENILAIAN PENGUJI PADA PESSTA+ S2 BERBASIS YII FRAMEWORK SEBAGAI MEDIA PENGINPUTAN NILAI SIDANG TESIS DI PERGURUAN TINGGI. SENSI Journal, 5(1), 63-72.

[4] Farozi, M., Suyanto, M., \& Lutfi, E. T. (2015). Perancangan Sistem Informasi Penilaian Kinerja Sumber Daya Manusia Menggunakan Metode Gamifikasi. Jurnal Teknologi Informasi Respati, 10(30).

[5] Sudaryono, S., Handayani, I., \& Nurmalasari, Y. (2018). Penilaian Pembimbing Sebagai Media Penginputan Nilai Mahasiswa Sidang Pada PESSTA+ di Perguruan Tinggi. Technomedia Journal, 3(1), 84-97.

[6] Nurhafid, A. (2017). Tinjauan Atas Penyusunan Anggaran Dan Realisasinya Sebagai Alat Penilaian Kinerja Perusahaan Pada PT Taspen (Persero) KCU Bandung (Doctoral dissertation, STIE Ekuitas).

[7] Kadafi, M., \& Amirudin, A. (2017). PENYUSUNAN STANDAR OPERASIONAL PROSEDUR (SOP) PROGRAM STUDI DI POLITEKNIK NEGERI SAMARINDA YANG MENGACU PADA PENILAIAN STANDAR AKREDITASI BADAN AKREDITASI NASIONAL PERGURUAN TINGGI (BAN-PT) MENGGUNAKAN PROGRAM MIND MANAGER DAN MICROSOFT VISIO. PROSIDING SNITT POLTEKBA, 2(1), 256-259. 